\title{
損傷許容発現先進無気孔型 $\mathrm{SiC}$ の熱衝撃破壊特性*
}

\author{
松田伸 也*1, 高橋学*2, 尾上拓 史*3 \\ 黄木景二*2, 松下 正 史*2 \\ 岡 部 永 年 ${ }^{* 4}$, 大藤 弘 明*5
}

\section{Thermal Shock Fracture Properties of Damage-Tolerant Advanced Pore-Free SiC}

\author{
Shinya MATSUDA*6, Manabu TAKAHASHI, Takushi ONOUE, \\ Keiji OGI, Masafumi MATSUSHITA, \\ Nagatoshi OKABE and Hiroaki OHFUJI \\ ${ }^{* 6}$ Graduate School of Science and Engineering, Ehime University, \\ 3 Bunkyo-cho, Matsuyama-shi, Ehime, 790-8577 Japan
}

\begin{abstract}
In the present study, quench tests were carried out to characterize the fracture behavior of advanced pore-free $\mathrm{SiC}$ with damage tolerance during thermal shock. The residual strength of specimens after the quench tests was also measured. It is found that the critical temperature difference and the decrease in residual strength of this material are larger than those of conventional $\mathrm{SiC}$. This is because the fracture is dominated only by flaw size since the wake zone is not generated during thermal shock with high strain rate. The critical temperature difference as well as the crack propagation is calculated with the aid of the unified theory of thermal shock.
\end{abstract}

Key Words: Advanced Pore-Free SiC, Critical Temperature Difference, Residual Strength, Inclusion, Damage Tolerance, Griffith's Theory, Unified Theory of Thermal Shock

\section{1. 緒言}

セラミックスは，潜在欠陥を起点として脆性破壊を 起こすため, その強度は主に岡部らによって提唱され た統一的評価法 ${ }^{(1)}$ のような 2 母数ワイブル統計解析に 基づいた信頼性評価がされている. しかしながらセラ ミックスも完全な脆性材料ではなく, 多孔質セラミッ クスで見られるクラック進展実験での R カーブ挙動 ${ }^{(2)}$ や球圧子押込み試験による接触部の局所的損傷 ${ }^{(3)}$ など のように，微視的な損傷が起こっても全体破壊には慗 がらない. すなわち若干ながら損傷許容性が備わって いる. セラミックスの適用をさらに拡大するためには 損傷許容性を定量的に把握し，信頼性評価法を精密化 する必要がある. 現在, 基礎的力学試験に基づいたこ れらについての研究が除々に行われつつある ${ }^{(4)}$. しか

\footnotetext{
* 原稿受付 2008 年 1 月 28 日.

*1 正員, 愛媛大学大学院理工学研究科博士後期課程 (业 7908577 松山市文京町 3$)$.

*2 正員, 愛媛大学大学院理工学研究科生産環境工学専攻.

*3 学生員, 愛媛大学大学院理工学研究科博士前期課程.

*4 正員, フェロー, 愛媛大学サテライトオフィス東京(忢1080023 東京都港区芝浦 3-3-6).

*5 愛媛大学地球深部ダイナミクス研究センター(函790-8577 松山市文京町 2 番 5 号)

E-mail : t851004y@mails.cc.ehime-u.ac.jp
}

しながらセラミックスは高比強度, 而熱性, 耐摩耗性 などの優れた機械的特性を有するため航空・宇宙分野 などのエンジニアリング材料としての適用が期待され ているにもかかわらず，これらのような環境下を想定 した場合での損傷許容性評価についての研究事例はほ とんど報告されていない(5)〜 (7).

近年, 奇抜な発想に基づいた従来の反忘焼結法を改 良することによって先進無気孔型 $\mathrm{SiC}$ (Advanced Pore-Free SiC, 以下 APF-SiC と称する. ) (8) が開発さ れた. APF-SiC は無気孔を形成しているため従来の反 応焼結 SiC 材に比べて, およそ2倍の曲げ強度を有し, また優れた損傷許容性が創出される材料である（詳細 な破壊メカニズムは次節にて説明する. また APF-SiC の損傷許容性とは，外力によって発生した微視的な損 傷がそのまま全体破壊に至らない性質と定義する.）． これまで著者らは，基礎的な強度特性と損傷許容性の 関係について研究を行ってきた ${ }^{(9)} \sim(12)$ が，実機適用 には様々な環境における強度特性や損傷許容性の影響 を調査する必要があり, 強度信頼性の面でいまだ多く の課題を残しているのが現状である.

そこで本研究では，APF-SiC を対象として冷熱環境 下を想定した液中急冷熱衝撃試験を行い，残存強度を 測定するとともに, FEM解析により損傷を誘起させた 
応力状態について調査した. これらの結果に基づき， 損傷許容性の発現について考察し, 従来のセラミック スと比較することによって基礎的熱衝撃破壊のパラメ 一タである臨界温度差およひ残存強度低下に及ぼす支 配要因について定性的に検討した. そしてこれらの妥 当性を立証するために力学モデルを構築し, 熱衝撃破 壊発生およびき裂進展を定量的に評価した.

\section{2. 実験方法}

\section{2 -1 APF-SiC の破壊および損傷許容举動メカニズ}

ム図 1 に示すように, 焼結中に金属シリコンと反 応できなかった複数の炭素同士によって形成している 数十 $\mu \mathrm{m}$ のコイン状の同素体 (以後, 介在物と称する.) が形成されて，ほぼ均一に分布しており，これの滑り によって APF-SiC は破壊する.このサイズは，従来の 反応焼結 $\mathrm{SiC}$ 材 (Reaction sintering $\mathrm{SiC}$; 以下 RS-SiC と 称する.）の破壊に関与する久陥サイズに比べて非常 に小さいために，約 2 倍のバルク曲げ強度を誇る.ま た内部には多数の遊離 $\mathrm{Si}$ も均一に分布しており, これ が主に優先的に損傷することで損傷許容性が創出され る $^{9) \sim(11)}$.

$2 \cdot 2$ 供試材 試験片は矩形形状であり, 参考文 献（8）に基づいて製造し，提供された先進無気孔型 $\mathrm{SiC}$ 材 (APF-SiC : $\left.{ }^{w} 4 \times^{\prime} 3 \times{ }^{l} 20 \mathrm{~mm}\right)$ と比較のために，市 販されている従来の反応焼結 $\mathrm{SiC}$ 材 (RS-SiC : ${ }^{w} 4 \times 3 \times$ ‘'40mm）を用いた. APF-SiC は試験片数に限りが あるため短いロッドに加工して使用した. それぞれの 機械的・熱的特性を表 1 に示す. RS-SiC の熱的特性は 参考文献 (8) に示されている他社製の反応焼結 $\mathrm{SiC}$ 材 のデータを用いた. ここで APF-SiC は RS-SiC に比べ

て曲げ強度が高くなるにもかかわらず，その見掛け上 のヤング率 $E$ は若干低下している.このことは従来か ら提言されているヤング率と理論的破壊強度との相互 関係に反している.この原因は，ファインセラミック スの弾性率測定法（JISR1602 規格）に基づいて $E$ を測 定した際，多くの微視的な損傷が発生（損傷許容性の 創出）することによって大きなひずみが生じたためで

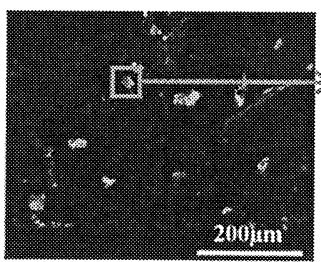

(a) Elements distributions of carbon from EDS.

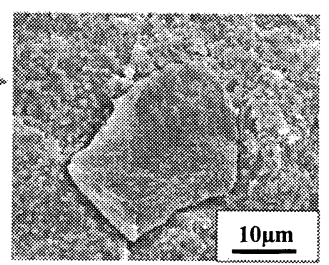

(b) Inclusion.

Fig.1 Fracture origin of APF-SiC.

Table 1 Physical properties of APF-SiC and RS-SiC.

\begin{tabular}{ccc}
\hline Materials & APF-SiC & RS-SiC \\
\hline $\begin{array}{c}\text { Fracture toughness } \\
K_{I C}\left[\mathrm{MPa} \cdot \mathrm{m}^{1 / 2}\right]\end{array}$ & 4.1 & 4.1 \\
\hline $\begin{array}{c}\text { Young's modules } \\
E[\mathrm{GPa}]\end{array}$ & 376 & 420 \\
\hline $\begin{array}{c}\text { Poisson's ratio } \\
\nu\end{array}$ & 0.16 & 0.17 \\
\hline $\begin{array}{c}\text { Density } \\
\rho\left[\mathrm{Mg} / \mathrm{m}^{3}\right]\end{array}$ & 3 & 3 \\
\hline $\begin{array}{c}\text { Thermal conductivity } \\
\lambda[\mathrm{W} / \mathrm{m} \cdot \mathrm{K}]\end{array}$ & 130 & 120 \\
\hline $\begin{array}{c}\text { Specific heat capacity } \\
c[\mathrm{~J} / \mathrm{k} \cdot \mathrm{K}]]\end{array}$ & 700 & 600 \\
\hline $\begin{array}{c}\text { Thermal expansion coefficient } \\
\alpha\left[10^{-6} / \mathrm{K}\right]\end{array}$ & 4.5 & 4 \\
\hline & & \\
\hline
\end{tabular}

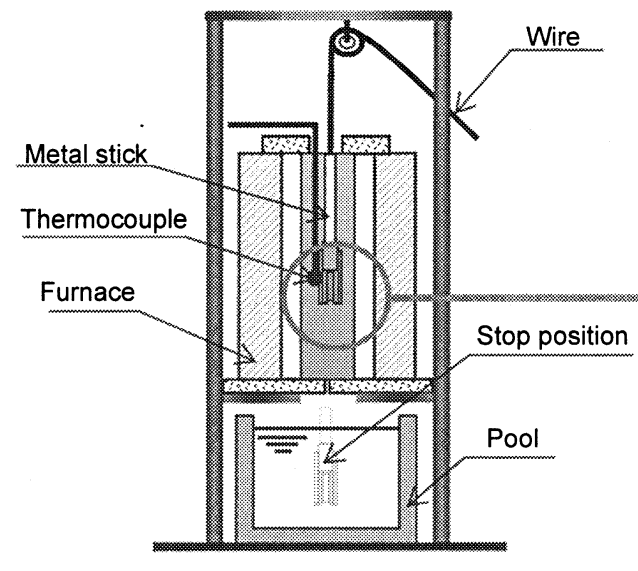

(a) Testing apparatus.

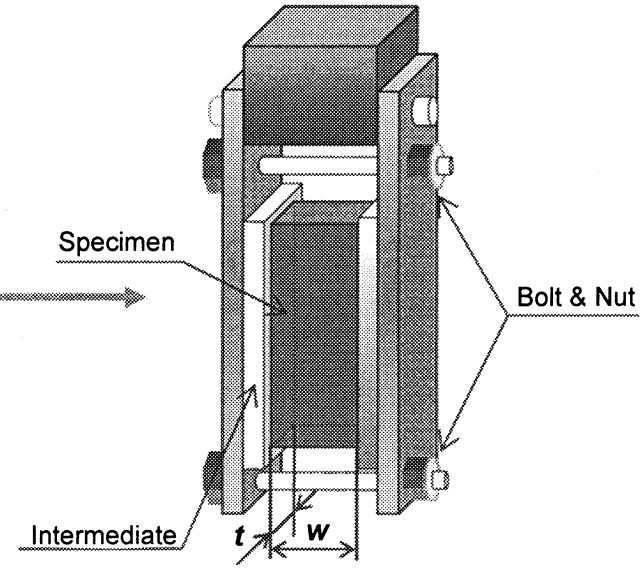

(b) Prepared specimen.

Fig.2 Schematic for thermal shock test. 
ある（この詳細は文献（9）を参照のこと）.

$2 \cdot 3$ 熱衝撃試験と残存強度試験 液中急冷熱衝 撃試験機および試験片の固定方法の概略を図 2 に示す. 加熱源として市販されている電気炉を用い，温度は熱 電対（アルメルークロメル線）によって測定した. 試 験方法は，まず図 2 (b) のように試験片を固定した治 具にワイヤーを直接取り付け，図2（a）のように炉の 中心部に吊るして 1 分間に $333 \mathrm{~K}$ の昇温速度にて所定 の温度まで加熱した．その際，炉内での加熱位置を揃 えまた垂直に投下して冷却するために，金属の中空 棒をワイヤーに通して治具先端に固定した. そして所 定の温度に到達後, 30 分間保持したのちに自由落下に て液媒に金属中空棒と試験片を治具に固定したままの 状態で投下させて泠却した．液媒には試料周りの沸騰 を防ぐため沸点の高いシリコンオイル（信越シリコー ン社製）を用い，その温度は $298 \mathrm{~K}$ 一定とした。 その 後, 常温大気中・クロスヘッド速度 $0.5 \mathrm{~mm} / \mathrm{min}$ にて曲 げ試験を行った. APF-SiC は試験片が小型であるため 3 点曲げ試験（下スパン $L_{l}=15 \mathrm{~mm}$ ) を行い, RS-SiC は 4 点曲け試験 (上スパン $L_{2}=10 \mathrm{~mm}$, 下スパン $L_{3}=30 \mathrm{~mm}$ ) を行った. APF-SiC と RS-SiC の残存強度 $\sigma_{R-A P F}$ 'および $\sigma_{R-R S}$ は,

$$
\begin{aligned}
& \sigma_{R-A P F .}{ }^{\prime}=3 P_{A P F .} L_{1} / 2 w t^{2} \\
& \sigma_{R-R S .}=3 P_{R S .}\left(L_{3}-L_{2}\right) / 2 w t^{2}
\end{aligned}
$$

によって評価した. $P_{A P F,} P_{R S}$ はそれぞれの試験におけ る破壊荷重 $[\mathrm{N}]$ である. ここで, $\sigma_{R-A P F}{ }^{\prime}$ と $\sigma_{R-R S}$ では試験 方法の相違による寸法効果に依存してしまうためその まま直接比較することはできない. 一般的にこのよう な寸法効果による曲げ強度の相関は, Davies が提唱し た有効体積の概念を適用すると本実験で設定した 4 点 曲げ試験と 3 点曲げ試験における同じ材料の強度 $\sigma_{4}$ と $\sigma_{3}$ の比は,

$$
\frac{\sigma_{4}}{\sigma_{3}}=\left(\frac{3 L_{1}}{L_{3}(m+3)}\right)^{1 / m}
$$

のような関係を得ることができる ${ }^{(13)}$ 。ここで $m$ はワ イブルパラメータ (形状母数) である. そこで式 (2) 八，後述する図 7 にも記載しているが著者らの研究に より明らかにしている APF-SiC のワイブルパラメータ $m_{b-A P F}=11.9$ を適用して $\sigma_{R-A P F^{\prime}}$ を 4 点曲げ強度 $\sigma_{R-A P F_{0}}$ ר 変換することで $\sigma_{R-R S .}$ と比較した.

2.4 FEM 解析による非定常熱応力解析 汎用 FEM 解析ソフト（MSC. Marc）を用いて，各材料の実 験から得られた臨界温度差 $\Delta T_{C}$ での非定常熱応力解析

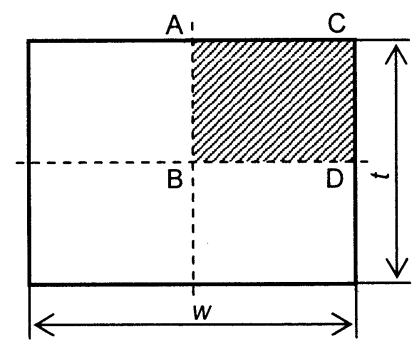

(a) FEM Analysis region.

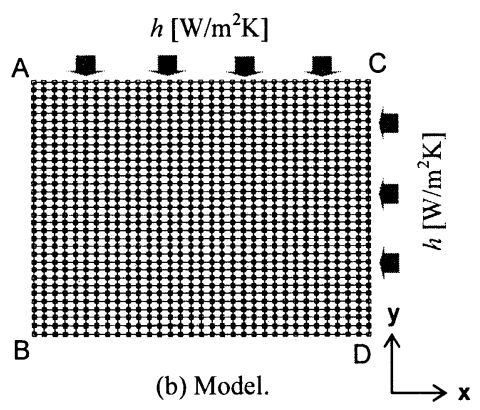

Fig.3 Model for thermal stress analysis.

を行った. 熱衝撃による応力の厳密な解析は困難であ るため，温度のみ非定常性を考慮しており，時間は一 パラメータとして取扱った. また材料特性の温度依存 性は無いと見なして表 1 の物性值を与え, 熱伝達率 $h\left[\mathrm{~W} / \mathrm{m}^{2} \mathrm{~K}\right]$ は一定であり, ビオ一数 $\beta=20$ と仮定して次 式より算出した.

$$
h=\frac{\beta \alpha}{w}
$$

また解析モデルとその境界条件を図 3 に示す，モデ ルは $1 / 4$ とし, 要素のセグメント幅は約 $625 \mu \mathrm{m}$ であり, 平面ひずみ問題として解析した。 なお, 解析には 4 接 点アイソパラメトリック四角形要素を用い, 要素数は 約 1000 である.

\section{3. 熱衝撃試験および FEM 解析結果}

図4に各材料の残存強度 $\sigma_{R}$ およ゙炬内とシリコンオ イルの温度差 $\Delta T$ の関係を示す．また APF-SiC につい ては Suyama ら ${ }^{(14)}$ のデータも加えて示す. これから APF-SiC は RS-SiC と同様, 臨界温度差 $\Delta T_{C}$ が現れ, その後の任意温度において $\sigma_{R}$ は低下する傾向を示した. このことから， APF-SiC の熱衝撃破壊は脆性個体であ るため, RS-SiC のような従来のセラミックスの破壊形 態 ${ }^{(15)}$ と同様, 局所的な熱応力によって介在物を基点 として若干の SCG 挙動を伴ってき裂が発生し, それが 不安定進展することによって破壊する（この破壊挙動 を伴った破壊を熱衝撃破壊と呼称する. ). そのため, 


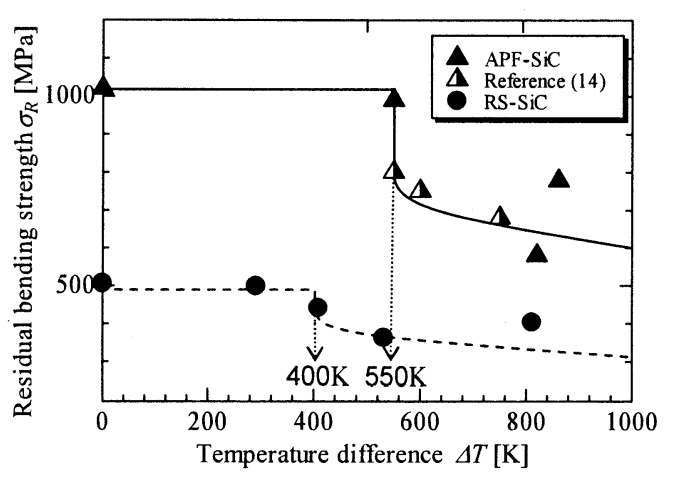

Fig.4 Relationships between residual strength and temperature difference of APF-SiC and RS-SiC.

残存強度試験を行った際，破壊部が起点となるために $\sigma_{R}$ は低下していると言えよう.

さてそれぞれの熱衝撃破壊特性について比較する と, APF-SiC と RS-SiC の臨界温度差 $\Delta T_{C-A P F}$ と $\Delta T_{C-R S}$. は約 $550 \mathrm{~K}$ と $400 \mathrm{~K}$ であり，また $\Delta T_{C}$ を超えた任意の温 度において APF-SiC の $\sigma_{R}$ は, ばらつきはあるが RS-SiC よりも高いことがわかる. ゆえに APF-SiC は RS-SiC
よりも熱衝撃に対して非常に優れた材料である. しか しながらそれぞれの $\Delta T c て ゙ の \sigma_{R}$ と処女材の強度を比較 した場合, RS-SiC は約 70MPa 程度しか低下していな いのに対して, APF-SiC は約 $200 \mathrm{MPa}$ 程度と大きく低 下している.

図 5 に FEM 解析から得られた各材料の $\Delta T c$ におけ る $\mathrm{x}$ 方向の最大引張熱忘力 $\sigma_{x-\max }$ 発生時のコンター図お よび図 6 に A 部の時間 $t$ の変化に対する引張熱応力 $\sigma_{x}$ の関係を示す。ここで各 $\sigma_{x-\max }$ は, $\sigma_{R}$ が低下している温 度での熱応力であるため, 熱衝撃破壊に要した応力と いえる. 両材ともに極表面層の中央付近で $\sigma_{x-\max }$ が短時 間で発生し, 深さ方向に対して急激に圧縮応力に変化 している.これは熱応力に曝された部材の典型的な応 力場であり，熱衝撃破壊は極表面層で起こることが予 想される. また APF-SiC および RS-SiC の $\sigma_{x-m a x}$ は 730MPa と 461MPa であり, APF-SiC は破壊が起こるた めに RS-SiC のおよそ 1.6 倍の引張熱応力が必要である. さらに図 7 にワイブル確率紙に整理した各材料の 4 点 曲げ強度 $\sigma_{b}$ と $\sigma_{x-\text { max }}$ を示す. RS-SiC は $\sigma_{b}$ と $\sigma_{x-\max }$ がほぼ 同等である.このことは，熱応力が曲げ強度より大き

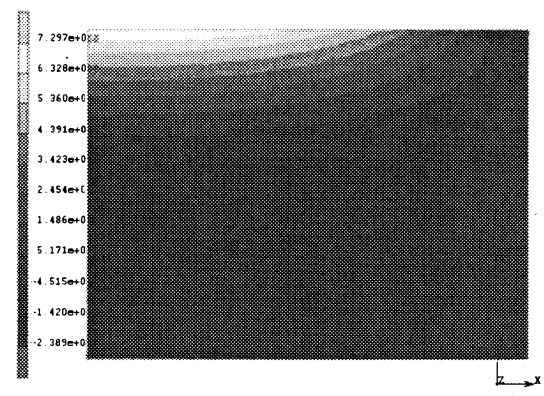

(a) APF-SiC

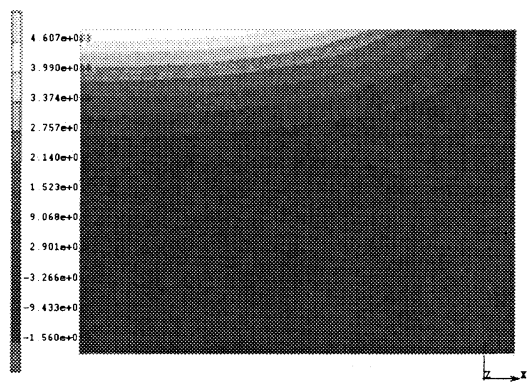

(b) RS-SiC

Fig.5 Stress distributions of $\mathrm{x}$ direction of APF-SiC and RS-SiC at critical temperatures.

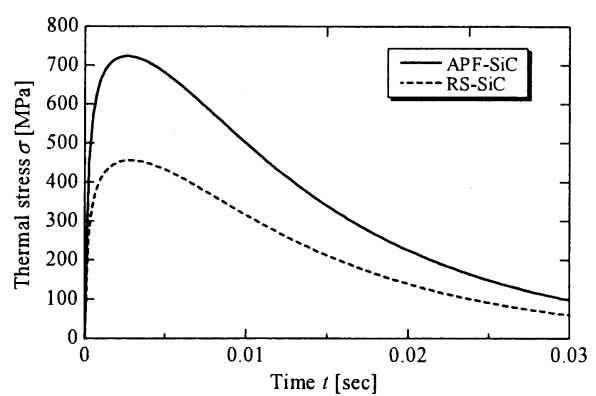

Fig.6 Relationships between thermal stress and time on surface center of APF-SiC and RS-SiC.

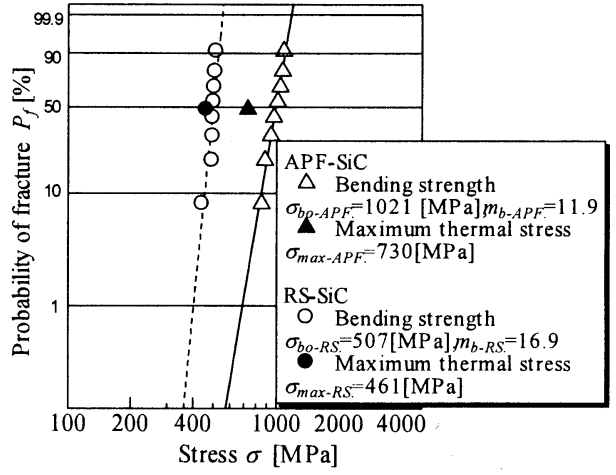

Fig.7 2-parameter Weibull distributions of 4-point bending strength and maximum thermal stress of APF-SiC and RS-SiC. 
くなると破壊が発生することを示唆している. しかし ながらこれに対して APF-SiC は， $\sigma_{x \rightarrow m a x}$ が若干低い傾向 が見られた。

\section{4. 考察}

$4 \cdot 1$ 損傷許容性 図 8 に $\mathrm{APF}-\mathrm{SiC}$ の 4 点曲什強 度 $\sigma_{b-A P F}$ および解析から得られた臨界温度差における $\mathrm{x}$ 方向の最大引張熱応力 $\sigma_{\text {max }-A P F}$ 之応力速度 $\dot{\sigma}$ の関係を 示す．ここで $\dot{\sigma} は$ 各破壊応力 $\sigma_{f}$ とそれに到達するまで の時間 $t_{f}$ の関係より,

$$
\sigma_{f}=\dot{\sigma} t_{f}
$$

のような見かけ上の線形関数として算出した. 従来の セラミックスの強度は図中の実線で示すように 下に伴って低下することがよく知られている．しかし ながら APF-SiC は領域 “I ”に示すようによが遅い場 合， $\sigma_{b-A P F}$ は上昇する. この原因は，部材が負荷される ことで遊離 $\mathrm{Si}$ の損傷が優先的に起こりプロセスゾーン (16) に類似した破壊抵抗領域が介在物周辺に現れるこ とによってすべりは妨げられる，その結果，強度上昇 を招いている. しかしながら領域 “II”のように向が 速い場合, 強度は若干ながら上昇する.このことは $\dot{\sigma}$ 増加に伴い，遊離 $\mathrm{Si}$ の損傷量が減少する。 その結果, 破壊抵抗領域がほとんど現れず，介在物のすべりによ る破壊が支配的となり，従来のセラミックスと類似し た破壊挙動を示す．よってこの結果は, 損傷許容性の 程度は。に支配されていることを示している(これら の詳細は文献（10）および（12）を参照のこと）。こ

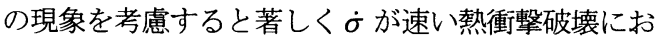
いては，このような破壊抵抗領域は創出されないと考 えられる.ここで 3 節にて述べたが, 領域” III での 曲け強度と $\sigma_{\text {max-APFF }}$ は若干異なっている. この原因は領

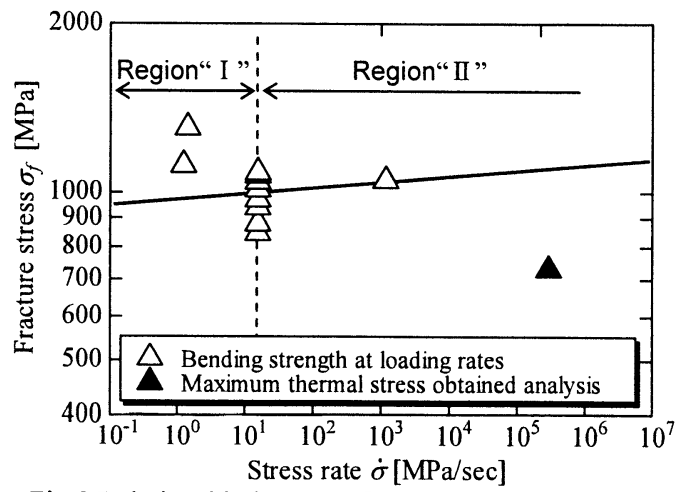

Fig.8 Relationship between fracture stress and stress rate.
域 “II” での曲け破壊は損傷許容がほとんど発現しな いとみな寸ことができるが, 熱衝撃破壊と比較すると， この $\dot{\sigma}$ は遅いために若干ながらも損傷許容が発現し ていると言えよう．そのために若干の相違が現れてい るものと考えられる.

$4 \cdot 2$ 臨界温度差両材の臨界温度差 $\Delta T_{C}$ の相違 を熱衝撃によるき裂発生に対する抵抗值（熱衝撃破壊 抵抗係数） $R$ の概念から検討した. $R$ は発生した熱灾 力の值が部材の破壊強度に等しいとして算定される $\Delta T_{C}$ のことであり，平板表面において次式にて表され る. (17)

$$
R=\Delta T_{C}=\frac{\sigma_{\max }(1-v)}{E \alpha}
$$

ここで $\sigma_{\text {max }}$ はき裂の発生に必要な熱応力である. 式 (5) より $R$ は $\sigma_{\text {max }}$ が高く, ヤング率 $E$ やポアソン比 $v$ およ び熱膨張率 $\alpha$ が小さいほど高いことが容易に理解でき る.ここで表 1 より各材料の $v$ と $\alpha$ はほぼ同等であり， Eについても APF-SiC が若干低い程度であるため, こ れらの影響による $R$ の差はほとんどない。しかし APF-SiC の熱衝撃破壊には従来材と比較して約 1.6 倍 の引張熱応力が必要であった. すなわち $\sigma_{\text {max }}$ は 1.6 倍 の差があり，これが $R$ を決定すると言える.このこと は破壊力学的観点から考察すると, APF-SiC は前述の 考察より熱衝撃破壊に対する損傷許容性が創出されな いと考えられるため, 両材のき裂発生に必要なこの熱 応力は破壊の起点となる欠陥サイズのみに依存するこ とを示唆している. ゆえに APF-SiC の破壊起点である 介在物は, RS-SiC の破壊起点より明らかに小さいため, この $\Delta T_{C}$ は高くなる. このことは言い換えるとグリフ イスの理論に従っていることを意味しており，欠陥寸 法が小さくなれば熱衝撃破壊においても理論強度に近 づくことを示している.

$4 \cdot 3$ 残存強度 各材料の臨界温度差 $\Delta T_{C}$ での 残存強度低下の差は熱衝撃破壊の大きさに依存する. つまり熱衝撃によって発生したき裂の不安定進展量に 支配されるといえる. そこで次式に示寸き裂進展に対 する程度を表すパラメータ（熱衝撃損傷抵抗係数） $R$ ” の概念から両材の相違について検討した. $R^{\prime \prime} は$ ，き裂 が発生した瞬間に部材内に蓄えられている熱ひずみに よる弾性エネルギーがすべてき裂進展に消費されると して以下の式にて与えられる. ${ }^{(17)}$

$$
R^{n}=\frac{E \gamma}{\sigma_{\max }^{2}(1-v)}
$$


ここで， $\gamma$ はき裂成長に必要な破壊エネルギーであ る. APF-SiC は前述したように損傷抵抗領域が創出さ れないことから両材の $\gamma$ は,

$$
\gamma=\frac{K_{I C}{ }^{2}}{2 E}
$$

より得られると仮定できよう. 式 (6) より，Eや $\gamma$ は 両材ともにほぼ同じであるが前述したようにき裂の発 生に必要な熱応力 $\sigma_{\text {max }}$ が 1.6 倍ほど違う.すなわちき 裂が発生した瞬間にRS-SiC よりも1.6倍の熱ひずみに よる弾性エネルギーを蓄えることを意味しており，不 安定き裂進展量が 1.6 倍違うことを示している. した がって APF-SiC は破壊に関与する欠陥サイズが小さい ために蓄えた熱ひずみエネルギーが大きくなり，その 結果進展量が大きくなるために残存強度の低下は大き くなると考えられる.

\section{$4 \cdot 4$ 臨界温度差と残存強度の予測による検証} $4 \cdot 1 \sim 4 \cdot 3$ 節での考察に対して理論的な観点から定量 的に検証した. APF-SiC は図1のように介在物が分布 しており，これを起点として破壊すると考えられる. そこで単位体積当たり $N$ 個の円板状欠陥が 3 次元的に 均一に分布していると仮定する. そして熱衝撃により 各々の欠宿からき裂は発生するが, 熱衝撃前後で $N$ と ポアソン比 $v$ は一定であり, 損傷許容性の影響は無く, 欠陥相互の干渉はないと仮定する.ここでグリフィス の理論に準じていることが実験的に明らかとなったた め, 熱ひずみによる材料の単位体積当たりの全エネル ギー $W_{t}$ は Hasselman が提唱している熱統一理論 ${ }^{(18)}$ に 基づいて,

$$
W_{t}=\frac{3\left(\alpha \Delta T_{C}\right)^{2} E_{o}}{2(1-2 v)}\left(\frac{1}{1+k N c^{3}}\right)+2 \pi N \gamma c^{2}
$$

として与えた. 右辺の第一項は熱ひずみによって蓄え られた弾性エネルギー, 第二項は破壊の起点となる欠 陥の破壊エネルギーを示している.ここで $c$ は半長欠 陥長さ， $k$ は任意定数であり,ここでは 3 次元ランダ 么分布欠陥の場合を想定し， $k=16(10-3 v)(1-2 v) / 45(2-v)$ としている. また $E_{o}$ は欠陥のない材料のヤング率であ $\eta$, 久陷密度 $\varepsilon=N c^{3}$ を導入すると, $E_{o}=E(1+k \varepsilon)$ とし て表わされる. そしてグリフィスの一般的なアプロー チからき裂発生のための条件として, $d W t / d c=0$ が成立 するので $\Delta T_{C}$ は,

$$
\Delta T_{C}=\sqrt{\frac{8 \pi \gamma(1-2 v)}{9 E_{o} \alpha^{2} k}}(1+k \varepsilon) \frac{1}{\sqrt{c}}
$$

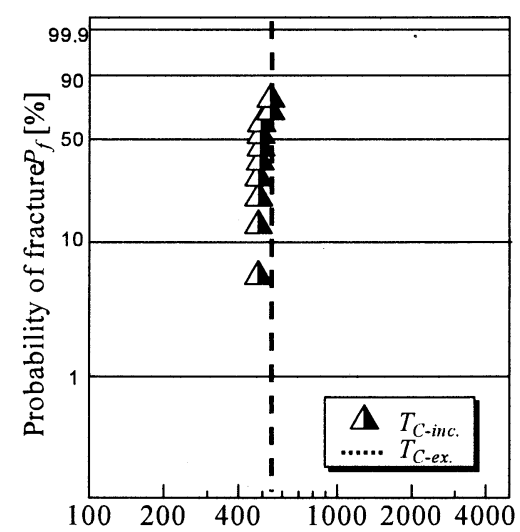

Calcurated critical temperature difference $\Delta T_{c}[\mathrm{~K}]$ Fig.9 2-parameter Weibull distribution of calculated critical temperature difference.

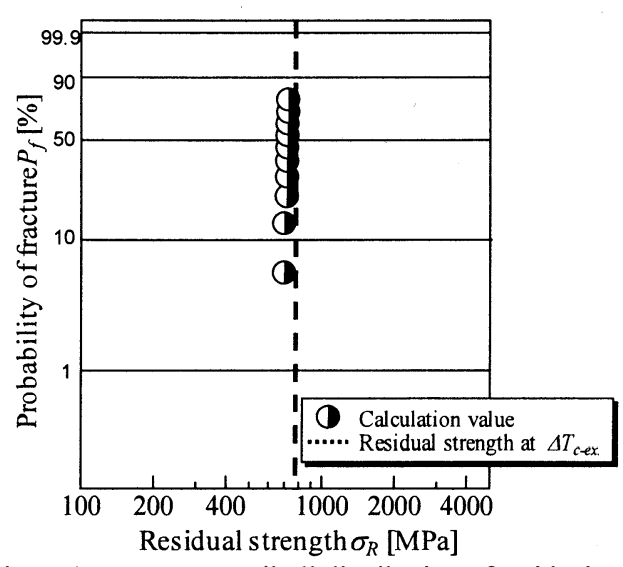

Fig.10 2-parameter Weibull distribution of residual strength value of calculation and experimental.

として与えられる ${ }^{(19)}$. この力学モデルを基に図 1 か ら介在物の半長 $c_{i n .}$ およびその個数を測定して $\varepsilon$ を決定 し, $c=c_{\text {m }}$.として $\Delta T_{C}$ を推定した後, これをワイブル確 率紙に整理した. また $c_{\text {inc. }}$ は形にばらつきがあるため 個々の最も長い値を測定し， $\varepsilon$ 算出にはそれらを平 均して算出した. 図 9 に実験值の $\Delta T_{\text {Cex および算出し }}$ た $\Delta T_{\text {C- in. }}$ のプロットを示す.これより，プロットは

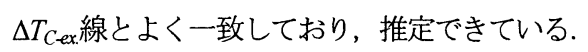

さらに介在物周りにおいて蓄えられたエネルギーが すべてき裂進展に費やされるとすると，最終き裂長さ $c_{f}$ は，式（8）を $W_{t}\left(c_{\text {imc. }}\right)=W_{t}\left(c_{f}\right)$ とすることによっ $\tau$,

$$
\Delta T_{C}=\sqrt{\frac{4 \pi N \gamma(1-2 v)\left(c_{f}^{2}-c_{i n c .}^{2}\right)}{3 \alpha^{2} E_{o}\left\{\frac{1}{1+k N c_{i n c .}^{3}}-\frac{1}{1+k N c_{f .}^{3}}\right\}}}
$$



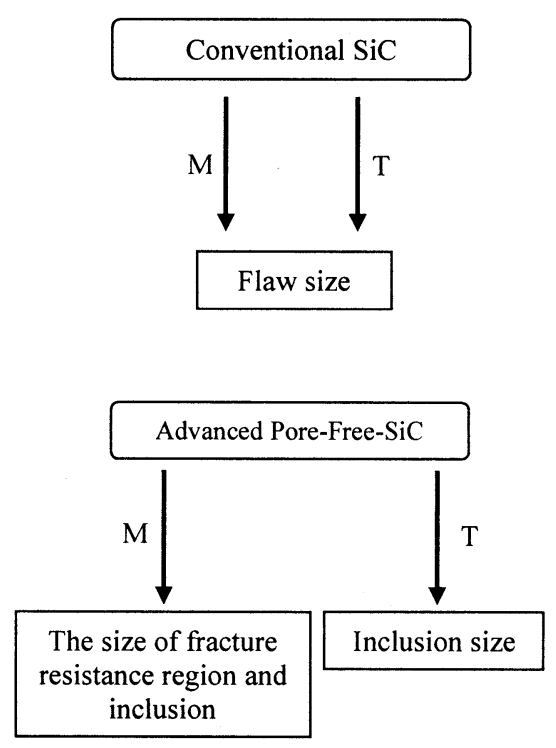

$\mathrm{M}$; Mechanical load, $\mathrm{T}$; Thermal shock

Fig.11 Flowchart of predominant factors on strengths property at various fracture types of APF-SiC and RS-SiC.

として与えられる ${ }^{(19)}$. これより図 9 に示している $T_{C-\text {-inc. }}$ での $c_{f}$ を式 (10) から算出し, 破壊じん性值 $K_{I C}$ を用いて参考文献 (20)に基づき残存強度を推定した.

図 10 にワイブル確率紙に整理した推定残存強度の結 果と害験から得られた $\Delta T_{C}$ での残存強度を破線にて示 す.このように推定残存強度は $\Delta T_{C}$ での残存強度とほ ぼ一致していることが認められる.すなわち熱衝撃に よって発生したき裂の不安定進展量を良く推定できて いることを示唆している.

以上の結果から次のように結論付けられる. 図 11 に RS-SiC のような従来のセラミックスと損傷許容性 を伴う APF-SiCの機械的負荷およひ熱衝撃に対する各 破壊強度の支配要因を示す，従来のセラミックスは， 負荷方式に関係なくその破壊強度は内在する欠陥サイ ズに支配される，一方，APF-SiC は，機械的負荷に対 しては損傷許容性を伴うため, 破壊強度は破壊の起点 となる介在物と破壊抵抗領域のサイズに支配される. しかしながら熱衝撃破壊の場合，破壊抵抗領域が創出 されない結果, 従来のセラミックスと同様に破壊の起 点となる介在物のサイズのみに支配される.

\section{5. 結言}

本論文では，優れた損傷許容性を有する先進無気孔 型 $\mathrm{SiC}$ (APF-SiC) を取り上げ，熱衝撃試験を行った. これより, 従来のセラミックスと比較することによっ て基礎的パラメータである臨界温度差およひ残存強度 低下に及ぼす支配要因について検討した。そその結果 APF-SiC は，従来のセラミックスと比較して臨界温度 差は上昇したが，残存強度は大きく低下した.これら は，熱衝撃環境下では変形速度が著しく速いため破壊 抵抗領域が創出されない結果, 熱衝撃破壊が欠陥サイ ズのみに支配されるからである。これらのことは APF-SiC の構造と類似したモデルを考慮している熱統 一理論を適用することによって定量的に評価すること で明らかとされた。

\section{文献}

(1) Okabe, N., Hirata, H., Muramatsu, M. and Hamada, S., Fracture Strength Properties and Unified Estimation Method for Structural Ceramics, Journal of The Society of Materials Science Japan, Vol.38, No.430 (1988), pp.783-788.

(2) Tanaka, K., Akiniwa, Y., Nomura, T. and Sakaida Y., Bending Strength of Smooth and Notched Specimens of Porous Silicon Carbide, The Japan Society of Mechanical Engineers, Vol.65, No.640 (1999), pp.2385-2391.

(3) Itabashi, Y., Matsumura, T. and Ochi Y., Fracture Strength of Porous Ceramics by Sphere Indentation, International Conference on Advanced Technology in Experimental Mechanics 2007, CD-ROM.

(4) Suzuki, A. and Baba, H., Assessment of Damage Tolerance and Reliability for Ceramics, Journal of The Society of Materials Science Japan, Vol.50, No.3 (2001), pp.290-296.

(5) Hayama, S., Ozawa, M. and Suzuki, S., Thermal Shock Fracture Behavior and Fracture Energy of $\beta$ '-Sialon-BN Composites, Journal of the Ceramic Society of Japan, Vol.104 (1996), pp.828-831.

(6) Tagashira, K., Obata, M., Sasa, T. and Mikami, T., Reliability of Ceramics Subjected to Thermal Shock by High-Speed Impingement Gas Cooling, The Japan Society of Mechanical Engineers, Vol.67, No.660 (2001-8), pp.1339-1344.

(7) Awaji, H., Thermal Shock Testing for Ceramics, Journal of The Society of Materials Science Japan,Vol.48, No.1 (1999), pp.1-9.

(8) Suyama, S., Itoh, Y., Kohyama, A. and Ktoh, Y., Development of High Strength Reaction-Sintered Silicon Carbide, Journal of the Ceramic Society of Japan, Vol.109 (2001), pp.315-321.

(9) Matsuda, S., Takahashi, M. and Okabe, N., Fracture Properties for Advanced Pore-Free SiC Dispersing of $\mathrm{Si}$ Particles, The Japan Society of Mechanical Engineers, Vol.73, No.732 (2007-8), pp.926-933.

(10) Matsuda, S., Takahashi, M., Matsushita, M., Ohfuji, H.and Okabe, N., Effects of Loading Rate on Fracture Properties of Advanced Pore-Free $\mathrm{SiC}$ Dispersing Si Particles, International Conference on Advanced Technology in Experimental Mechanics 2007, CD-ROM.

(11) Matsuda, S., Matsushita, M., Takahashi, M., Ohfuji, H. and Okabe, N., Study for the Origin of Fracture of Advanced Pore-Free Silicon Carbide with Damage 
Tolerance, Journal of the Ceramic Society of Japan, Vol.116, No.1 (2008), pp.126-129.

(12) Matsuda, S., Takahashi, M. and Okabe, N., Study for Loading Rate Dependence on Strength Properties of Advanced Pore-Free $\mathrm{SiC}$ with Damage Tolerance, Journal of The Society of Materials Science Japan, Vol.57, No.3 (2008), pp.292-296.

(13) Hoshide, T., Sakai, T. and Sakaida A., Probability Model of Material Strength (4) (Chapter 1 Probability Model of Fundamental Theory) (in Japanese), SCIENCE OF MACHINE, Vol.48, No. 10 (1996), pp.1089-1093.

(14) Suyama, S. and Ito, Y., Development of Applications for High-Strength Reaction-Sintered Silicon Carbide, TOSHIBA REVIEW, Vol.61, No.6 (2006), pp.72-75.

(15) Sakuma, T., Iwata, U. and Okabe, N., Probabilistic Estimation of Thermal Shock Fatigue Resistance of Ceramics, The Japan Society of Mechanical
Engineers, Vol.61, No.589 (1995-9), pp.1878-1883.

(16) Nishida, T. and Yasuda, Y., Mechanical Property Estimation of Ceramics, (in Japanese) (1986), pp.110-111, The Nikkan Kougyo Shinbun. LTD.

(17) The Ceramic Society of Japan, Advanced Ceramics (1991), pp.147 149, Ohmsha.

(18) D.P.H.Hasselman, Unified Theory of Thermal Shock Fracture Initiation and Crack Propagation in Brittle Ceramics, Journal of The .American Ceramic Society,Vol.52, No.11 (1969), pp.600-604.

(19) Ogi, K. and Takeda, N., Quantitative Evaluation of Thermal Shock Fracture of Brittle Materials Using a Gas-Quench Technique., Proceedings of the $34^{\text {th }}$ JSASS/JSME Structures Conference (1992),pp.30-33.

(20) Murakami Y., et al., STRESS INTENSITY FACTORS HANDBOOK, Vol.1, PERGAMON PRESS. 